\title{
Georgia Black Sea Coast Protection with Free Beaches
}

\author{
Alpenidze Melor ${ }^{1}$, Seperteladze Zurab², Davitaia Eter ${ }^{2}$, Gaprindashvili George ${ }^{2,3,4^{*}}$ \\ ${ }^{1}$ Department of Geography, Sokhumi State University, Tbilisi, Georgia \\ ${ }^{2}$ Department of Geography, Ivane Javakhishvili Tbilisi State University, Tbilisi, Georgia \\ ${ }^{3}$ Department of Geology, National Environmental Agency, Tbilisi, Georgia \\ ${ }^{4}$ Vakhushti Bagrationi Institute of Geography, Tbilisi, Georgia \\ Email: *gaprindashvili.george@gmail.com,melor07@mail.ru,zura_sep@mail.ru
}

How to cite this paper: Melor, A., Zurab, S., Eter, D. and George, G. (2018) Georgia Black Sea Coast Protection with Free Beaches. Journal of Geoscience and Environment Protection, 6, 151-167. https://doi.org/10.4236/gep.2018.65013

Received: April 7, 2018

Accepted: May 22, 2018

Published: May 25, 2018

Copyright $\odot 2018$ by authors and Scientific Research Publishing Inc. This work is licensed under the Creative Commons Attribution International License (CC BY 4.0).

http://creativecommons.org/licenses/by/4.0/

\section{c) (i) Open Access}

\begin{abstract}
In the paper, it is discussed reinforced coastal zones with resort-recreational functions, destructed in terms of anthropogenic pressure of the Black Sea, Georgia. Results of many years' observations and researches prove low effectiveness of active methods of coastal protection, mostly causing and provoking intensive degradation of the beaches. Article highlights developing and constructing of free and unbounded beaches as an optimal coastal protection approach. Successful example of this approach was developing of coastal zone in 90s, in Gagra (West Georgia), Black Sea. Positive impact of this kind of artificial beach still survives. In the thesis, it is presented an attempt to scientifically prove extrapolation-traduction on the other similar coasts of the recovery of Gagra Zone beach. Based on morphodynamic analysis and comparison, according to the priorities of major features of reinforced coasts, it turned out that coast of three similar objects (Gagra, Ochamchire and Sokhumi) show homogenous aspects. Scientific expediency of providing extrapolation on other similar objects of etalon objects i.e. Gagra Beach recovered by successful coastal protection experiment. Thereby, for the purposes of creating free-artificial beach, choosing of wrecking zone of Ochamchire is based on coastal protection effectiveness and economical principals, including technical-economical effectiveness.
\end{abstract}

\section{Keywords}

Georgia, Black Sea, Coast, Beach, Coastal Protection, Extrapolation, Analogue-Object

\section{Introduction}

On modern stage, tendency of social-economic development of the region is di- 
rected towards the coasts of seas and oceans, which confers the system of "Sea-Coast-land" united territorial, social-economical and geo-ecological importance, verifies its strategic potential and basis to sustainable economic development. Based on the materials of Environment and Sustainable Development UN Conference (Rio De Janeiro, 1992) and local legislative instruments, expediency of recovery, protection and regulation [1] of anthropogenically destructed coasts of the Black Sea is proved.

Major aim of the thesis is research of anthropogenic transformation of sea coasts and spatial-temporal negative changes, modern recovery methodology-constructing of free beaches on similar-objects and scientific prove of extrapolation method in practice. Solution of the given problem includes two tasks:

1) Revealing-mapping of reasons and consequences of spatial-temporal anthropogenic transformation;

2) Scientific proof of advantage of the rational (reasonable) coverage of coastal recovery and protection (constructing of free artificial beach) in comparison with traditional approaches of coastal protection;

Geo complexes of coastal zone (dynamic units of the coast) are the individual territorial units [2] and have own signs of natural conditions (regimen of surging and deposition, beach material balance, etc.), feeding sources of deposition, deposition movement and accumulation zones, forms of anthropogenic impact and scales, character and quality of economic usage.

Appearance of the coastal line created by natural factors [3] [4] [5] [6] [7], has suffered strong anthropogenic pressure during the last century (off-flowing of deposition from the beaches, construction of hydro-power stations and ports, unreasonable coastal protection), including visible unacceptable [8] [9] [10] [11] transformation (washing over the beaches, coastal abrasion). Not very often, their tendency became irrevocable and coastal infrastructure faced catastrophic destruction. Resort-tourist and transport infrastructure mostly are located in 3 $5 \mathrm{~m}$ from the sea line [12] [13]. Acceleration of sustainable economic development, marine turnover [14] and construction of ports [15] of the country means increasing of coastal risks, which requires recovery, protection and keeping of sustainability of the coasts.

\section{Study Area \& Methods}

Black Sea coast of Georgia includes the space between the River Psou and the River Chorokhi $(315 \mathrm{~km})$. Within these limits, according to the geotectonic partition, two types [16] of underwater slope (deep-steep and shallow-sloping) fragment corresponds. The first one covers the slopes with shallow slopes of Bichvinta, Sokhumi and Batumi and Underwater canyons and the other includes vast shallows of Gudauta and Ochamchire. Most part of the both types of coasts was faced to strong anthropogenic pressure in XX century and required coastal protection activities. Research of the authors includes wrecking fragments of the 
coasts. Avoiding of beach washing and abrasion of major coasts, on resort and industrial sea lines (Gagra, Gudauta, New Athoni, Sokhumi, Ochamchire, Poti, Kobuleti, Batumi) is provided mostly via reinforced construction (points, walls, wave breakers, tetrapods, dipods). Considering of long history of their usage in practice (more than a century), they do not show significant positive effect. Resistance of coasts and sea disasters for many centuries incurred in creation and usage of many types coastal protection constructions. They used to build walls to protect the coast from intrusion of sea waves; though wave power $\left(35-40 \mathrm{t} / \mathrm{m}^{2}\right)$ quickly caused $(10-12 \mathrm{~mm})$ their destruction [17]. Wave breakers provoked washing of beach materials into the sea, formation of digging the basis of constructions [18], generation of bottom backflows, together with decreasing of wave power. Wide usage of point series (Gagra, Tuapse, Sochi, Gudauta, Sokhumi, Ochamchire) and long-term exploitation, with its major function to create the basis of local accumulation of the beach, didn't bring any desirable coast protection result of this type of constructions. Thus, it was necessary to search for new approaches for protecting the coasts-instead of reinforced constructions, elaborating of modernized and free beaches of old type (XVIIIc). Launching of this idea into practice was successfully attempted near New York-on Long Island Beach, where until the 50s of the last century, constructing of point series didn't bring any positive results. In 1951-52, in FRG, $1.8 \mathrm{mln} \mathrm{m}^{3}$ sand materials were brought for coastal protection, and 10 years later, the same was introduced in France and Portugal. Creating of artificial beach and coastal protection was reached in $30 \mathrm{~km}$ coastal line of Spain, including wrecking sea zones of Italy, Japan and Netherlands. Total length of coasts protected by artificial beaches in the USA is $600 \mathrm{~km}$, with $300 \mathrm{mln}$ tones of sand beach, Long Island Seal beach $(50 \mathrm{~km})$ with $4 \mathrm{mln} \mathrm{m}^{3}$ sand in total.

Similar works were carried out on the sand beaches of Gelendzhic (Russia) and Crimea (Ukraine), Azov and Baltic Seas.

Successful experiment of beach recovery and creating of free beach was carried out in Black Sea Coast [19] in Georgia as well (Gagra zone) (Figure 1). Though, in 90s of the last century, due to famous devastating occurrences in Georgia (civil wars), formation of free beaches was interrupted. Wrecking condition of the coast and dangerous development requires urgent activities for keeping the sustainability of the beaches. Thus, using of this unique experiment in other similar beach bears great practical expediency.

Solution of the principle goals and tasks of the thesis required using of various geographical methods, including the following:

1) By using spatial-temporal changes of morphodynamics of the coasts and comparative-geographical methods helped to search for objects with morphodynamic features, comparison of their natural features and anthropogenic transformations;

2) Multifactorial method includes using of comparative analysis of occurrences, spatial-temporal reflection, mapping and geo-informative approaches.

3) Maximum provision of evaluation coastal processes is based on usage of 


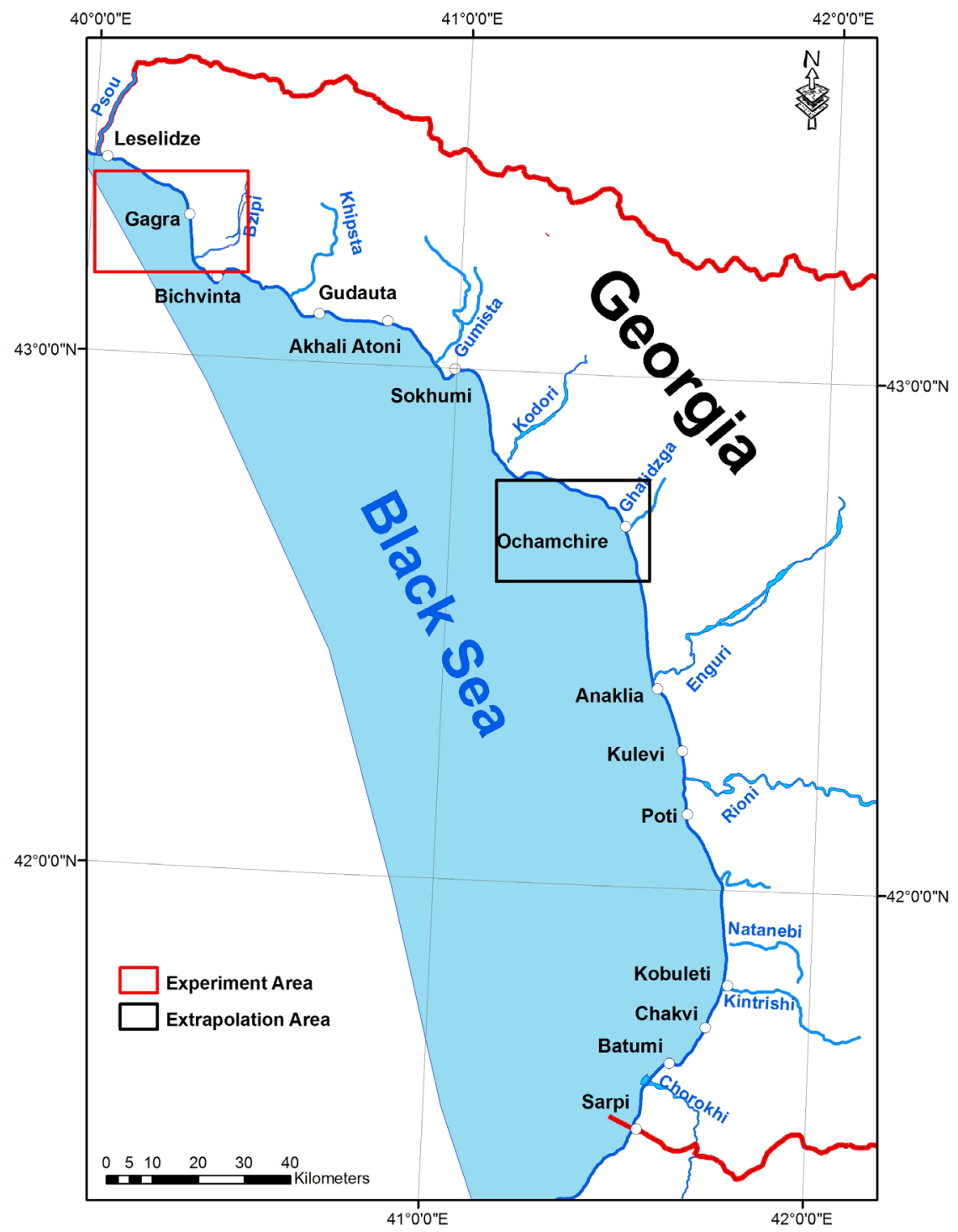

Figure 1. Black sea coast line in Georgia.

extrapolation method-launching of observation-based conclusions on one part (or on occurrence) of the occurrence or on the other occurrence. This action requires comparison of the two occurrences and based on this, launching of extrapolation. Solution of the task is based on finding similar-objects, standing out their leading factors and underlining and comparing of their internal features. Precondition to success is the existence of some similarity between the occurrences. No doubt that extrapolation is based on analog method or analogization-finding of relevant similar-objects, analogs in nature. High quality of approach i.e. homogeneity of similar objects provides evaluation of morphodynamic features of coast with any accuracy and moreover, generalization on other similar objects. Simultaneously, traduction method is used as well, which makes it impossible to spread specific or general information (knowledge) of one object onto another object. 
On the next stage of the research, it is important to set factors and features of the objects according to the functional priorities. 6 objects are recognized as similar-objects of the research coast-zones of Gagra, Gudauta, New Athoni, Sokhumi, Ochamchire, Kobuleti and Batumi. Each of them includes essential natural and anthropogenic features and is characterized with quantitative-qualitative index.

It is obvious that, quality of representatively of this index depends on selection of major parameters of morphodynamic features of the coast (cliffs, beaches, abrasive slopes, sources, etc.), including effect of the received parameters (speed of abrasion and washing, volume of alluvium, etc.) on natural reality. 10-10 factors were verified as leading factor of morphodynamic for each object (Table 1)-geological-geotectonic, lithologic, hydrologic components, beach parameters, anthropogenic pressure, types of coastal protection, etc. Detailed information about each similar-object allows us to compare indexes of leading factors of coastal components and internal features, which finally is the mean to group similar-objects according to the similarity quality. From all possible features of leading factors of similar-objects, like from 900 cases, we have 626 cases having the similar features (Table 2).

Table 2 shows real $(\mathrm{R}=30)$ and nominal $(\mathrm{N} \leq 30)$ rates of similarity of each similar-object's features, including the total of nominal rates of these similarities- Nn, specific share of its real rate (NnX100:Rn) indicates on closing possible similarities to reality. Thereby, from the number of cases of possible similarities in comparing features of the similar-objects (626), Gagra, Ochamchire, partially Sokhumi and Kobuleti objects are characterized with the highest index. Natural, anthropogenic leading factors and features of Gagra (76\%), Ochamchire (73\%) and Sokhumi (70\%) are distinguished with vivid similarity. Thus, it is possible to arrange the similar-objects, according to the similarity quality of features:

1) Different-less than average $(<20.9)$ with total features $(<69 \%)$;

2) Similar-equal to the average with common features;

3) Homogenous - more than average $(<20.9)$ with total features $(>69 \%)$.

According to the similarity quality of similar-objects, major importance of such arrangement and especially, its practical meaning is that in case of vivid affinity of similar features on coastal zones, it is possible to accomplish extrapolation-traduction of already successful coastal protection of one object onto another similar-object.

For the purposes of recovery, protection and long-term exploitation of coastal line, comparison of common and different aspects of leading factors and internal features of thoroughly researched object (etalon-object) with the similar features. For this purpose, we have to review advantages and disadvantages of liquidation works of negative impacts of anthropogenic pressure of Black Sea Resort-Gagra Coast and analyze experimental coastal protection activities realized in 80 s.

Thereby, we have to indicate that etalon-object of the coastal zone should satisfy the following conditions: possibility to measure the parameters, modeling 


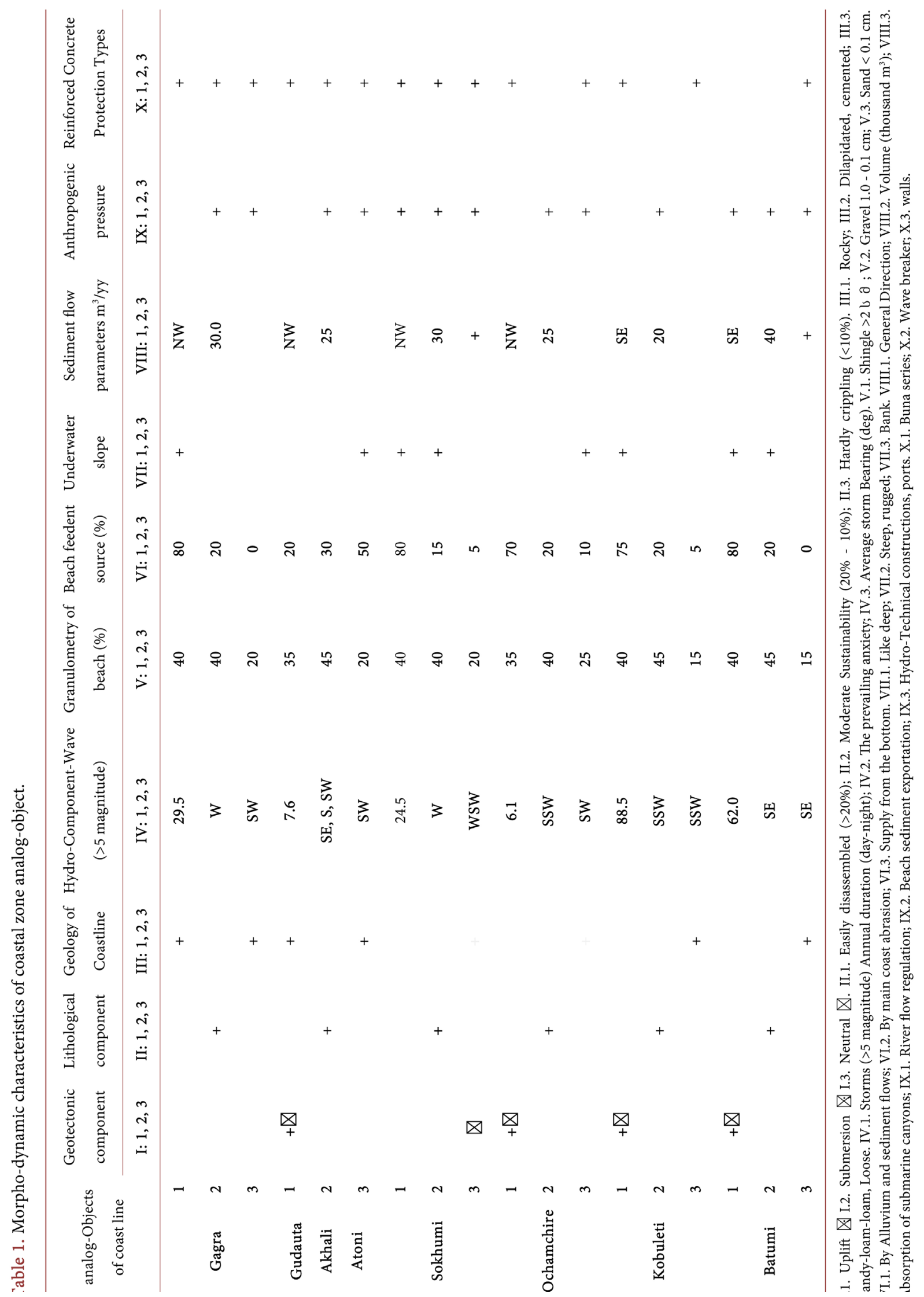


Table 2. Comparison of internal features of the leading factors of similar objects.

\begin{tabular}{|c|c|c|c|c|c|c|c|c|}
\hline \multirow{2}{*}{$\begin{array}{l}\# \\
1\end{array}$} & \multirow{2}{*}{$\begin{array}{c}\text { Analogue-Objects } \\
\text { Gagra }\end{array}$} & \multicolumn{4}{|c|}{ Analog-Objects of shore nominal $(\mathrm{N})$ features similarities values } & \multirow{2}{*}{$\begin{array}{r}\mathrm{N}_{\mathrm{n}} \\
114\end{array}$} & \multirow{2}{*}{$\begin{array}{l}\mathrm{N} \text { av } \\
22.8\end{array}$} & \multirow{2}{*}{$\frac{N_{n} \Xi 100: R_{n}(\%)}{76}$} \\
\hline & & & 25 & 25 & 22 & & & \\
\hline 2 & Gudauta, AkhaliAtoni & 23 & 19 & 24 & 19 & 99 & 19.8 & 66 \\
\hline 3 & Sokhumi & 25 & & 21 & 20 & 105 & 19.8 & 70 \\
\hline 4 & Ochamchire & 25 & 21 & & 23 & 110 & 22.0 & 73 \\
\hline 5 & Kobuleti & 22 & 20 & 23 & & 106 & 21.2 & 71 \\
\hline \multirow[t]{2}{*}{6} & Batumi & 19 & 20 & 17 & 22 & 92 & 18.4 & 61 \\
\hline & Sum/Average & 114 & 105 & 110 & 106 & $626 / 104$ & 20.9 & 169 \\
\hline
\end{tabular}

ability of process extrapolation, fulfilling virtual role model of physical realization [20]. Selecting of Gagra Coastal perimeter as etalon-object of coastal zone was conditioned as a result of long-term (20 - 70s of XX century) and strong anthropogenic (lower washing out, withdrawing of beach materials) pressure, with unreasonable (reinforced constructions) coastal protection, strong destruction of the coast, highly positive effect of successful coastal protection experiment (constructing of free, artificial beach).

While evaluating experimental free beach of Gagra coast, possibility of comparison of research results on etalon-object with the similar-object bears essential importance. Homogeneity of features of etalon-object (Gagra artificial beach) and similar-object should allow us to introduce extrapolation and traduction of successful coastal protection of the first one onto another.

Sokhumi and Ochamchire similar-objects show maximum similarity with the features of Gagra etalon-object (25 features from 30). Selecting of Ochamchire coastal object as preferential object is conditioned by some additional principles of keeping natural face of coast and improving it: 1) identity principle of components-similarity of free beach and granulometry applicable alluvium; 2) Optimality principle-maximum economical effectiveness due to affinity with the similar-object.

For scientific proof of extrapolation-traduction on similar-object (Ochamchire coast) of constructing of Gagra free beach, authors consider it appropriate to discuss quantitative-qualitative features of anthropogenic transformation of coast and morphodynamic signs of coasts.

Gagra coastal perimeter falls within extreme north-western lithodynamic system of Black Sea of Georgia and is the transit zone of coast line flow. Active process of its destruction and degradation starts back in the beginning of the last century (1914-1916). Then, near the outfall of the River Zhoekvara coast began to crawl forward and beach was being accumulated near leeward side of surrounding field of the Gagra Port. As a result, on its windward side active washing of the beach began [21] [22]. Later (1923-1924), for the purposes of coastal protection, they used crib points $(15-20 \mathrm{~m})$ filled with huge stones on wind- 
ward side of the port. Though, they couldn't protect the coast, process of beach washing was increased. Decreasing of active washing was neither provided by protecting walls, point series and wave breakers. Step by step, these constructions provoked "under washing" process.

Washings caused by blocking of alluvium flow (in 1959-1968) were comparably less damaging and was about 40 thousand $\mathrm{m}^{3} / \mathrm{ss}$ [23]. At the distance of 3.0 $\mathrm{km}$, on the north side of this coastal zone of Gagra, for the purposes of coastal protection at the outfall of the River Kholodnaia Rechka, constructing of point series (1970-1972), incurred in formation of stabile beach on windward side of this zone. At the leeward side, due to exhaustion of beach material, active abrasion was formed, coastal protection of which required arrangement of tetra pods and large stones. In the period of 10 years exploitation of this construction, loss of alluvium was about 400 thousand $\mathrm{m}^{3}$, in the beginning of $80 \mathrm{~s}$ number reached catastrophic level (Figure 2) and stability of some sanatoriums faced danger. Building of reinforced construction on wrecking coast (wave breakers, tetra pods) didn't help, washing process on its south-east direction continued intensively.

Later (1968-1982), during the period of active point series construction, destruction of the beach accelerated and increased to 900 thousand $\mathrm{m}^{3}$. Maximum phase of washing coincide with the total washing of sand and grit in the zone of surf and stripping of easily decomposed layers of lake-laguna genesis, clay and turf (with age of 4.0 - 4.6 thousand years). These relict residues, within the area of modern morphodynamic processes, fall into the last phase of total washing of sand-grit alluvium (with $4.0 \mathrm{~km}$ length). For example, in storm during one single winter (1981-1982), coast crawled backwards with $20 \mathrm{~m}$ and city coast faced the catastrophe (Figure 3) [24]. Finally, on $4.0 \mathrm{~km}$ Gagra coast 38 points were constructed, including coast-protecting and wave-breakers; time to time gaps between the points were filled with pebbles.

Given situation required new type of coast-protection. Purpose of constructing of experimental beach was to verify advantages and disadvantages of artificial beach-formation, namely evaluation of technical-economical parameters of coast protection, selecting and checking of optimal technology for mobilizing alluvium on wrecking coast. Among them, the most important one is successful extrapolation-traduction of free beach formation, for the purposes of pebble coast protection (Figure 4).

On the first hand (1982), artificial mobilization of alluvium was carried out on local zones (so called deformed point) of $3.0 \mathrm{~km}$ perimeter of the River Zhoekvara, village of Thkhemi. Volume of artificial mobilization of alluvium (to the port field) up to the village of Tkhemi and outfall of the River Zhoekvara turned up to be 890 thousand $\mathrm{m}^{3}$ in 1982-1988. It gave positive result and beach space was increased to $4.5 \mathrm{~h}$. Coast line crawled forward in $25 \mathrm{~m}$ on average and in 40 $45 \mathrm{~m}$ in some places. Thereby, 350 thousand $\mathrm{m}^{3}$ materials were moved towards the alluvium flow from the experimental zone [24], causing coast stabilization 
on lower washing line (Figure 5). Thereby, additional mobilization of alluvium (360 thousand $\mathrm{m}^{3}$ ) increased the width of the beach up to $40 \mathrm{~m}$. Finally, volume of alluvium within the Gagra coastal perimeter in 1982-1990 was $2.5 \mathrm{mln} \mathrm{m}^{3}$, increasing the beach space in 21 times and 106 thousand $\mathrm{m}^{3}$ average volume of the alluvium (calculating as of per 1 hectare of the artificial beach). Besides, in 1990-1991, on Gagra coast, as a result of dismantling huge portion of point series, as an experiment, caused successful movement of alluvium, major reason of washing was avoided and recovery/renovation of "former" coast line flow began.

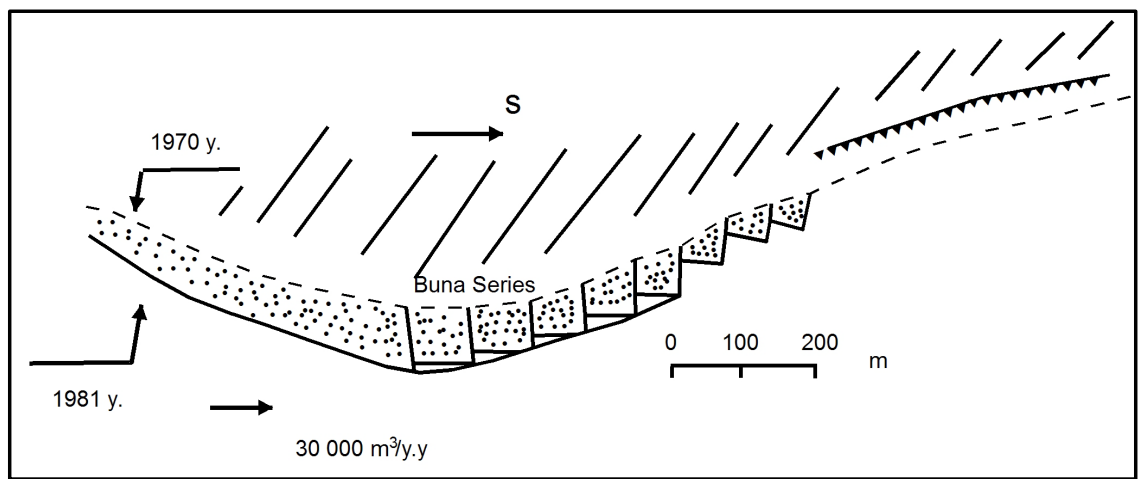

Figure 2. Dynamic of Kholodnaia rechka crest and adjacent coastline [23].

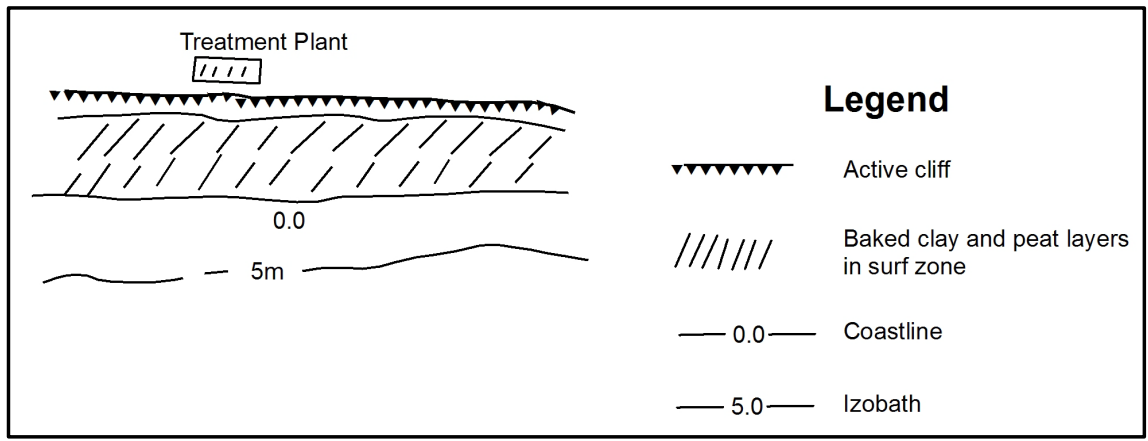

Figure 3. Wash away of the beach baring of clay layers [23].

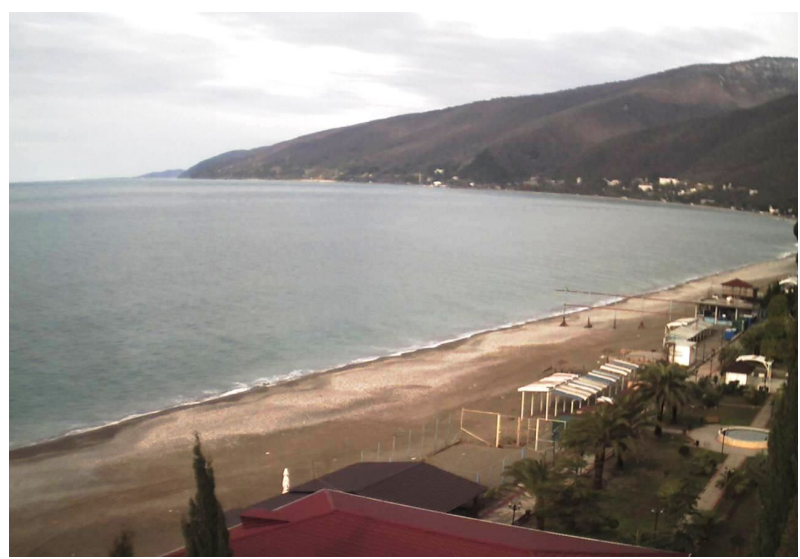

Figure 4. Gagra coastline. Restored Beach

(https://cn.webcams.travel/webcam/fullscreen/1210585029). 


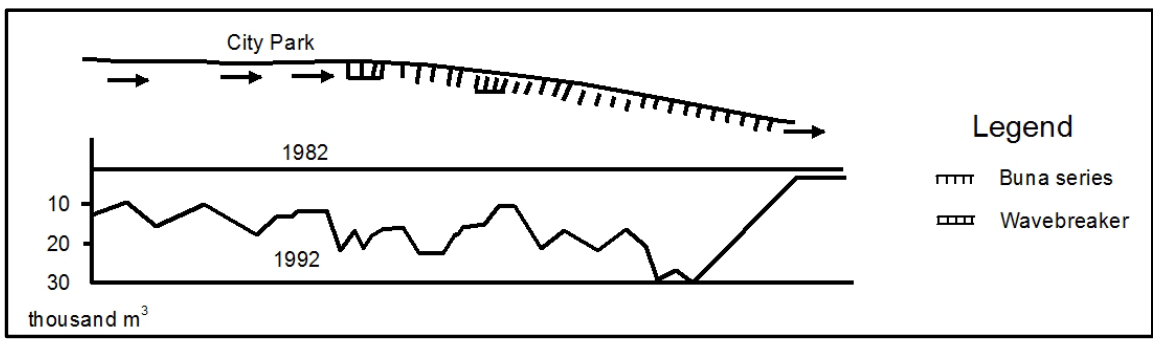

Figure 5. Dynamics of gagra coastline [23].

It is obvious that, coastal and beach line returned to its initial, before anthropogenic (natural) condition and stabile beach is kept for 25 years already. Thus, results of successful experiment of creating free beach, for coast protection purposes, while choosing of optimal action, construction of free beach bears scientific proof and practical aim, including: cutting of coastal protection expenses twice, economy of various deficit construction materials (cement, metal), decreasing of full repairing expenses, creating of alluvium active balance, preventing of abrasion reasons and under washing, recovery and keeping of natural environment, improving of sanitary-hygienic and esthetic condition, etc. Based on this, it is clear that creating of free beach is justified by due nature using, being socially acceptable, economically effective and safe in terms of geo-ecology.

Until 30s of the last century, Black Sea line of similar-object of Ochamchire coast, covered the space from delta of the River Kodori to the outfall of the River Enguri, in common alluvium transit zone, within the dynamic system of Kodori. On west part of city outskirts, due to port construction (1933-1934), coastline flow was discontinued and eastern coast line of port $(6.2 \mathrm{~km})$ showed "under washing", causing beach line washing, and then abrasion of major coast. Backward crawling of coast showed $5 \mathrm{~m} / \mathrm{ss}$, causing $10 \mathrm{~m}$ active cliff on the beach. Later (60s), $150 \mathrm{~m}$ width line of the coast was totally ruined within the city

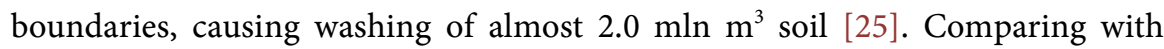
this, volume of accrued materials at port leeward $\left(200\right.$ thousand $\left.\mathrm{m}^{3}\right)$ is significantly (10 times) low, which can be explained by prevailing of abradable coast formatting easily decomposing and fine-dispersive clays (95\%-95\%). As clay fraction goes into deep waters by storm waves and cannot take part in beach material balance.

For the purposes of decreasing coast destruction and protecting from waves, in 60 s of the last century, wall $(3500 \mathrm{~m})$ and point series (56 units) were widely being constructed. Reinforced constructions needed constant repair and their gaps required to fill with pebbles from time to time. They began to construct point series on under washing zone, near the port and it served to keep the city and highway from abrasion. East section of port coast $(2300 \mathrm{~m})$ - was under active abrasion

Comparison of planning verified that, close to the port coast line crawled back in $250 \mathrm{~m}$ and totally $32 \mathrm{~h}$ of the coast was lost. Clay seabed of underwater space was stripped and vast bench was covered only with modestly thick alluvium. 
Exhaustion of ruined materials (sand, pebbles, grit) on clay bench bottom caused intensive corrosion of soft and non-stabile soil. Underwater observations showed that small "bottoms" (depth $30-40 \mathrm{~cm}$, width $1.0-1.5 \mathrm{~m}$ ) were formed on pebble fragments, on the surface of clay bench. Their number varies from 100 - 150 to 200 - 250 per $\mathrm{h}$, according to the storm power and duration. It is obvious that, exhaustion of beach material and stripping of bench surface are followed by irrevocable process of active abrasion of beach plateau.

Presently, coastal line reinforced with cement walls and point series, is not subject to alluvium artificial filling for the last 20 - 22 years and step by steps falls into risky/wrecking condition (Figure 6). Thus, in terms of beach material deficit, abrasion of bottom clay soil and turf layers were followed by destruction of coast-protection construction and active abrasion of city line (green zone of park).

As it seems, concrete approach of coast-protections of Ochamchire coast didn't give any positive result. Destruction of the coast and even of the coast-protection constructions is spotted. These facts prove purposefulness of rescuing of Ochamchire coast from wrecking condition, constructing of free beach and launching of Gagra coast-protection experiment on Ochamchire coast zone-similar object. For the purposes of alluvium artificial mobilization and free, boundless beach, windward side of Ochamchire port is provided for mobilization of alluvium and deforming point construction i.e. south washing zone of the port (Figure 7). Considering technical-economic effectiveness of huge amount of alluvium for creating artificial beach of Ochamchire, carrier of pebble material should be located preferably close to the artificial beach site.

While searching of beach material carrier, dried riverbed of the River Enguri located in 45 - $50 \mathrm{~km}$, on South-east side of Ochamchire should be considered. Constructing of arched dam of the River Enguri Hydro-Power Station and water reservoir caused its drying (length $62 \mathrm{~km}$ ). Until functioning of the River Enguri Hydro-Power Station, alluvium of the River Enguri fed Kolkheti Black Sea beaches [26] [27]. Due to sharp decrease of alluvium transportation, its conductibility was decreased as well. Volume of beach material brought by this river to the sea shore is about 30 thousand $\mathrm{m}^{3}$ and obviously, it doesn't take part in beach-formation process. Thereby, sanitary-hygienic contamination, including risk of flooding of inhabited areas and households by seasonal and episode freshets take place.

In case of extreme rise of river water expenditure $\left(2500 \mathrm{~m}^{3} / \mathrm{s}\right)$ [28], increasing of these risks in several steps up is expected. For the purposes of optimal nature using, it is preferred to clean the riverbed from "extra" ruined materials, which is above $450 \mathrm{mln} \mathrm{m}^{3}$ on this section of the riverbed.

Considering the economic-ecological aspects of creating free beach on seashore of Ochamchire and regulating the coast, it is possible to process alluvium accumulated in the riverbed of the River Enguri and transporting it via marine transport to the windward side of Ochamchire port. Distance from the riverbed 


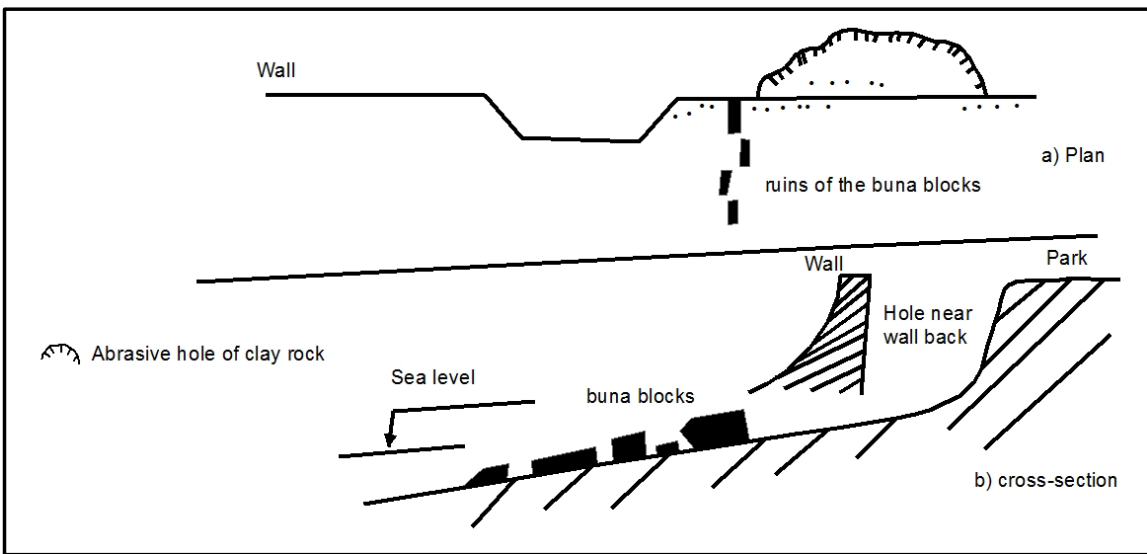

Figure 6. Ochamchire beach protective walls are damaged, buna is destroyed.

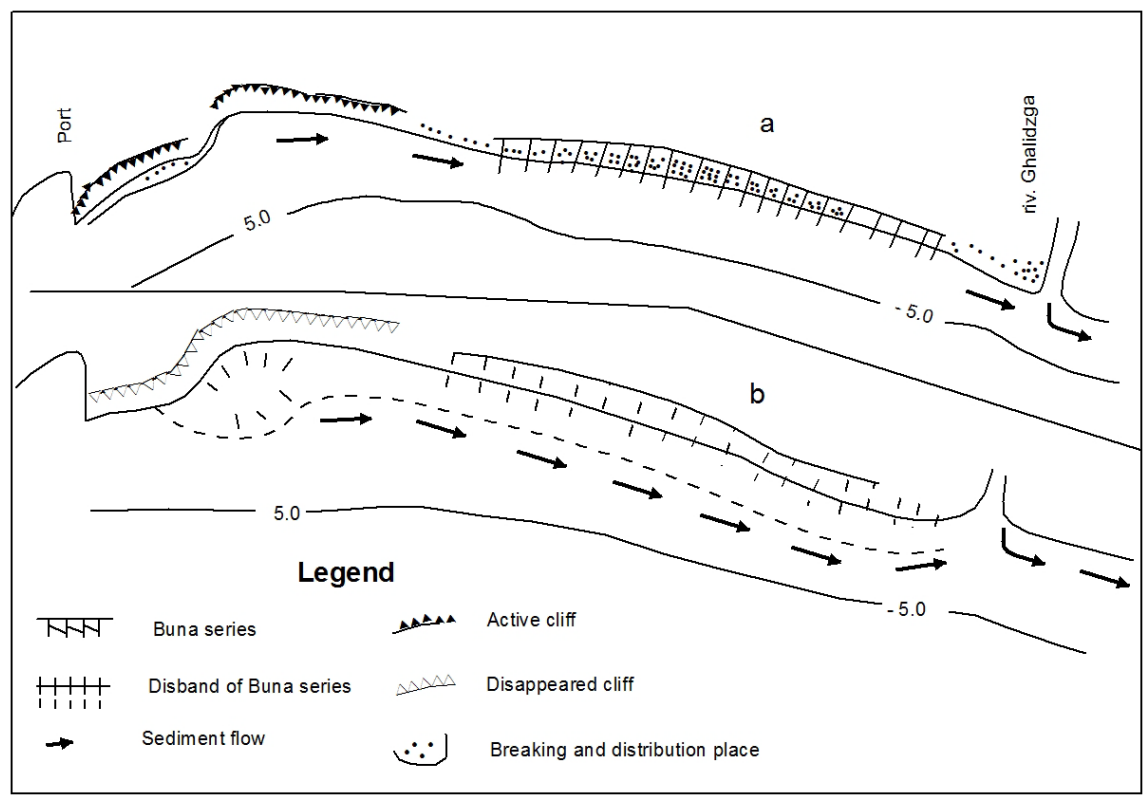

Figure 7. Modern artificial beach construction in Ochamchire and it's expected to change; a) Current State; b) Shore after free beach forming and Dismantling of Bunin series.

of the River Enguri to the beach mobilization zone is $50 \mathrm{~km}$, which relates to small expenses of transportation.

For verifying parameters of artificial beach volume, method of natural analogs or models gives trustful results. Basis is launching of quantitative parameters of coast morphodynamic as criterial experiment on experimental object. It considers important characteristics of natural regimen of beaches and statistical features of their dynamics and development. Versatility of advantages of the method is in its wide usage (minor corrections according to the specific beach). Artificial beach experiment (similar-object) on Gagra beach plays the role of natural model and via comparative-geographic approach allows us to verify beach prognosis.

Considering Gagra experiment of creating artificial beach and from pure 
geometric point of view, based on average width $(50-55 \mathrm{~m})$ of Ochamchire coast beach and slope of underwater hill ( $\mathrm{i} \leq 0.03$ ), per $1 \mathrm{~m} 2$ of artificial beach, with $4.0 \mathrm{~m}^{3}$ alluvium, we shall calculate the beach-forming fraction for creating deforming points, from the following formula:

$$
V_{0}=2 L \Delta B h,
$$

where $V_{0}$-volume of beach-forming material; $L$-beach projecting length; $\Delta B$-width of the beach; $h$-index of modern beach embankment

here,

$V_{0}=2 \Xi 6200 \Xi 50 \Xi 3,5=2170000$, or approx. $2.2 \mathrm{mln} . \mathrm{m}^{3}$

While prognosing traduction of specific results and conclusions onto another object i.e. spatial extrapolation of coast-protection activity i.e. we have to suppose that, extremely positive effect can be reached, as it depends on widely approved scientific methods and successful practice of free, artificial beaches.

Thus, using of experiment similar to Gagra coast protection on Ochamchire zone will cause deformation of "pebble point" and transportation of its materials towards reinforced point series. Mobilizing of artificial beach materials by south-west waves, in Ochamchire gulf will cause "regeneration" of former alluvium flow and wrecking points within the city under the beach materials (like Gagra points) will be "unclosed". Notwithstanding this, dismantling of head parts of separate points will be necessary. After refilling of the gaps left after dismantling of the points, alluvium will keep moving towards the river Ghalidzga outfall and finally towards the river Enguri, thus it will regain initial power (40 thousand $\mathrm{m}^{3} / \mathrm{ss}$ ). In the process of long-term exploitation of free beach ( $2-3$ decades), for the purposes of step by step pebble filling, "repassing" of alluvium accumulated on leeward side of Ochamchire port is possible.

Thus, based on analysis of anthropogenic transformations of coastal fragments and irrational coast-protection policy, recovery-protection of ruined coasts and introduction of regulatory-managing approaches are preferential. Considering local morphodynamic factors of the coast and "Geonic" principle, partial dismantling of active coast-protection constructions (point series, wave breakers, etc.) and construction of free beaches (deforming points) in practice are proved.

Possibility to diagnose and predict positive effect of spatial extrapolation of beach coast-protection activities is based on widely acclaimed and approved scientific methods, due to successful practice of free, artificial beach construction.

For the purposes of coast line stabilization of Ochamchire, creating of artificial free beach and copying of Gagra coast-protection experiment on Ochamchire similar-object is distinguished with scientific proof, as well as practical nature using aim. In order to create free, artificial beach, mobilization of alluvium and construction of deforming "pebble point" is recommended on "under washing" zone of leeward side of Ochamchire Port (Figure 7). Considering technical-economical effectiveness of constructing of artificial beach, carrier of 
"building pebble materials" is located in 45 - $50 \mathrm{~km}$ from south-east side of Ochamchire (dried riverbed of the River Enguri).

Using of alluvium accumulated in the riverbed of the River Enguri is pretty practical decision. As until functioning of the River Enguri Hydro Power Station (1974), alluvium of the River Enguri fed the Black Sea beaches [26] [27], though building of the dam decreased flowing of the alluvium towards the sea [29], thus it doesn't take part in beach-formation process. Thereby, there are high risks of sanitary-hygienic contamination, including flooding of inhabited areas and households. It is obvious that cleaning of the riverbed and using of alluvium in coast protection is complex environment protection activity.

Scientific proof and practical importance of free beach experiment on Ochamchire beach is obvious:

creating of alluvium active balance; preventing of abrasion reasons and under washing; recovery and keeping of natural environment, improving of sanitary-hygienic and esthetic condition; economy of various deficit construction materials (cement, metal); small doze of investments and exploitation expenditures; nature preserving function of free beach; avoiding negative impacts of point series; dismantling of reinforced coast-protection constructions and increasing of attraction of the beach; regaining of natural condition; turning destructing power of waves into "creative power", etc. Based on this, it is clear that creating of free beach is justified by due nature using, being socially acceptable, economically effective and safe in terms of geo-ecology.

As it seems, for verifying parameters of artificial beach volume, method of natural analogs or models gives trustful results. Basis is launching of quantitative parameters of coast morphodynamic as criteria experiment on experimental object. It considers important characteristics of natural regimen of beaches and statistical features of their dynamics and development. It is clear that based on Morphometric and morphodynamic parameters of Ochamchire coast, mobilization of alluvium for free beach $\left(2.2 \mathrm{mln}, \mathrm{m}^{3}\right)$, based on Gagra example, must prolong stability of the beach up to 25 - 30 years.

Extrapolation of artificial beach experiment as of natural model via comparative-geographic approach allows us to verify beach development tendency and verification of prognosis.

Vivid versatility of successful experiment allows using it widely (minor corrections according to the specific beach).

\section{Conclusions and Recommendations}

The following was verified according to the research:

- Irrevocable character of tendency developed in terms of strong anthropogenic pressure of coasts (construction of ports, power stations, withdrawing of beach materials, and river regulation), obvious negative prognosis and dangerous geo-ecological risks;

- For stabilizing coastal line abrasion and beach washing, strengthening of de- 
structive character of irrational (reinforced constructions) coast protecting activities;

- The purposefulness of recovery, keeping and improving natural conditions of coast, including avoiding of reinforced construction recurrence and introduction of natural-preserving approaches in coast-protection;

- Necessity of avoiding side effects of traditional (reinforced constructions) coast protection approaches, reasonable territorial organization of sea line and replacing of ruined beach with artificial analog and its intentional developing;

- Practical relevancy of partial dismantling of active coast-protection constructions (point series, wave breakers, etc.) and construction of free beaches (deforming points), considering local morphodynamic factors of the coast and "Geonic" principle.

- Purposefulness of launching positive coast protection experiment of constructing free, boundless beach on Gagra coast on other analog-objects (Ochamchire, Sokhumi, etc.).

- Extrapolation of artificial beach experiment as a natural model via comparative-geographic approach, verification of beach development tendency and verification of prognosis, including recognition of versatility of this approach and possibility of its wide usage on specific coast.

\section{Acknowledgements}

This research would not have been possible without the support of many people and also without using many scientific researches done by the staff of Sokhumi State University and the Department of Geography (Faculty of Exact and Natural Sciences) of Ivane Javakhishvili Tbilisi State University. Authors of the work express their gratitude to all them.

\section{References}

[1] The Law of Georgia (2006) About Sea, Reservoirs and River Banks Regulation and Engineering Protection (27.12.2006. \#4131).

[2] Alpenidze, M., Seperteladze, Z., Davitaia, E., Gaprindashvili, G., Aleksidze, T. (2015) Natural-Geographical Zoning and Geo-Ecological Problems of Georgia's Black Sea Coast. American Journal of Environmental Protection, 4, 58-66. https://doi.org/10.11648/j.ajep.s.2015040301.20

[3] Dunaev, N. (2012) The Contribution of Recent Tectonics in the State of the Sea Coast. Proceeding Seashores-Evolution, Ecology, Economy, Articles XXIV International Coast Conference, Tuapse, 1-6 October 2012, 152-155.

[4] Alpenidze, M. and Lomtatidze, G. (2011) Black Sea: Abiotic and Biotic Processes Dynamics. Abiotic Factors. Part I. Apkhazeti Science. National Academy of Sciences, Tbilisi, 235.

[5] Kaplin, P. and Porotov, A. (2012) Climate Change in the Late Holocene and the Development of Sea Shores of the Black Sea. Geomorphology, No. 4. 64-72.

[6] Kaplin, P. and Porotov, A. (2011) The Development of Coastal Systems of the Black 
Sea in Terms of Climate Change and Anthropogenic Impacts. Proceedings of the International Scientific Conference "Research and Development of Marine and Terrestrial Ecosystems in Arctic and Arid Climate", Rostov-on-Don, 6-10 June 2011, 161-164.

[7] Kaplin, P. and Porotov, A. (2010) Holocene Climatic Rhythms and Their Reflection in the Coastal Processes. Actual Problems of Stratigraphy and Paleogeography of the Pleistocene. Abstracts of All-Russia. Scientific Conference "Markov Readings 2010", Moscow, 28-30 October 2010, 37-38.

[8] Alpenidze, M., Seperteladze, Z. and Davitaya, E. (2013) Landscape and Environmental Problems Nature Manajement Black Sea Coast Kolkhida (The Effects, Perspective). I International Conference, Kolkheti Lawland Water Ecosystems-Protection and Efficient Use, Workbook, Tbilisi-Foti, 22-24 July 2013, 132-135.

[9] Zenkovich, V. (1987) Research of the Coastal Zone of the Black Sea within Georgia. In: Zenkovich, V.P., Ignatov, E.I. and Lukyanova, S.A.M., Eds., Natural Foundations of Coastal Protection, Nauka, 45-51.

[10] Fokina, N. (2006) Anthropogenic Factors Abrasion Processes. Proceeding Construction and Techno Genic Safety, 15-16, 138-142.

[11] Alpenidze, M., Seperteladze, Z. and Davitaia, E. (2008) The Black Sea Rational Nature Landscape-Ecological Research and Anthropogenic Processes-Management Regulation (Case Study: Georgia). Collected Papers: "Pressing Problems of Geography of Mountainous Regions", 329-341.

[12] Kobakhidze, E. (1971) Resort Agriculture and Tourism of Georgia Tbilisi.

[13] Kobakhidze, E. (1973) Natural Resources of Georgia, Tbilisi.

[14] Kolkheti Lowland (1990) Scientific Background and Development, 248.

[15] Zenkovich, V. (1976) Waiting for Changes in the Sea-Coast in the North of Kolkheti. Academy of Sciences of the Georgian SSR, 83, 637-640.

[16] Zenkovich, V. (1977) Coast of the Seas. Black Sea. Proc. General Characteristics and History of Caucasus Relief. Nauka, Moscow, 129-138.

[17] Zhdanov, A.M. (1963) Marine Shore Protection Structures. M., Transzheldorizdat, $87 \mathrm{p}$.

[18] Alpenidze, M. (1978) About the Latest Changes in the Coastline of the Sokhumi District. ANGSSR 1978 m. 90, No. 2, 397-399.

[19] Kiknadze, A., Meladze, F. and Sakvarelidze, V. (1984) Protection of the Black Sea coast of Georgia from the Erosion of the Sea. Gruz NIINTI, Tbilisi, 52.

[20] Pozharsky, S. (2012) Structured Approach to the Definition of the Term "Measure". GP State CMC, "Ray” Kharkiv, Metrology, 28-32.

http://www.metrology.kharkov.ua/fileadmin/user_upload/data_gc/conference/M20 12/pages/28.pdf

[21] Bozic, P. (1927) Studying the Movement of Coastal Sediments of the Black Sea. Math. Centre Gidrometbyuro, Vol. 7.

[22] Bozic, P. (1938) Scour the Sea Coast in Gagra. Training Notes of Moscow State University, 19.

[23] Peshkov, A. (2005) Pebble Beaches Tidal Seas. The Main Problems of the Theory and Practice. Krasnodar, 444 p.

[24] Peshkov, A. (1987) Artificial Pebble Beaches in the Marine Protection. USSR 
Academy of Sciences. On the World Ocean Commission, Nauka, 165-171.

[25] Alpenidze, M. (1975) The Rate of Abrasion and the Strain Seashore within the City Ochamchire. Collected Paper of Young Scientist Conference, Tbilisi, 110-111.

[26] Lominadze, G., Megreli, N. and Russo, G. (2006) Change of Black Sea Coastal Area (Central Part of Kolkhida, 1976-2002) under Influence of Man-Induced Factors. Change of Environment at the Turn of the Millennium. Tbilisi-Moscow, 133-139.

[27] Kiknadze, A. (1977) Dynamical Systems and Sediment Budget along the Black Sea Coast of Georgia. The Man and the Environment, Sukhumi, Alashara, 59-67.

[28] Alpenidze, M. (2007) Problems f Nature Use of Georgia Black Sea Coast. Collected Paper of Sokhumi State University, Volume 2, Tbilisi.

[29] Jaoshvili, Sh.V. (1986) River Sediments and Beach Formation on the Black Sea Coast of Georgia, Tbilisi. 